\title{
The need for a canonical reading of the Exodus narratives in finding its present-day theological significance
}

\begin{tabular}{|c|c|}
\hline $\begin{array}{l}\text { Author: } \\
\text { Gregory C. Per }\end{array}$ & eira ${ }^{1,2}$ \\
\hline $\begin{array}{l}\text { Affiliations: } \\
{ }^{1} \text { Department } \\
\text { Testament Stu } \\
\text { of Pretoria, So }\end{array}$ & $\begin{array}{l}\text { Old } \\
\text { dies, University } \\
\text { uth Africa }\end{array}$ \\
\hline $\begin{array}{l}{ }^{2} \text { North-West U } \\
\text { Potchefstroom } \\
\text { South Africa }\end{array}$ & $\begin{array}{l}\text { niversity, } \\
\text { campus, }\end{array}$ \\
\hline $\begin{array}{l}\text { Corresponden } \\
\text { Piff Pereira }\end{array}$ & ce to: \\
\hline $\begin{array}{l}\text { Email: } \\
\text { piff@btc.co.za }\end{array}$ & \\
\hline $\begin{array}{l}\text { Postal address } \\
\text { PO Box } 50710 \\
2125 \text {, South A }\end{array}$ & $\begin{array}{l}\text { Randburg } \\
\text { frica }\end{array}$ \\
\hline $\begin{array}{l}\text { Dates: } \\
\text { Received: } 20 \mathrm{~J} \\
\text { Accepted: } 13 \\
\text { Published: } 19\end{array}$ & $\begin{array}{l}\text { une } 2012 \\
\text { May } 2013 \\
\text { Aug. } 2013\end{array}$ \\
\hline $\begin{array}{l}\text { How to cite th } \\
\text { Pereira, G.C., } \\
\text { need for a can } \\
\text { of the Exodus } \\
\text { in finding its p } \\
\text { theological sig } \\
\text { Verbum et Ecc } \\
\text { Art. \#754, } 7 \text { pa } \\
\text { http://dx.doi.c } \\
\text { ve.v34i1.754 }\end{array}$ & $\begin{array}{l}\text { is article: } \\
\text { 2013, 'The } \\
\text { onical reading } \\
\text { narratives } \\
\text { resent-day } \\
\text { nificance', } \\
\text { lesia } 34(1) \text {, } \\
\text { ages. } \\
\text { org/10.4102/ }\end{array}$ \\
\hline $\begin{array}{l}\text { Note: } \\
\text { This article is t } \\
\text { dissemination } \\
\text { study under th } \\
\text { of prof. J.H. le } \\
\text { Department o } \\
\text { Testament Stu } \\
\text { of Theology, U } \\
\text { Pretoria. }\end{array}$ & $\begin{array}{l}\text { he } \\
\text { of a PhD } \\
\text { e supervision } \\
\text { Roux, } \\
\text { f Old } \\
\text { dies, Faculty } \\
\text { niversity of }\end{array}$ \\
\hline $\begin{array}{l}\text { Copyright: } \\
\text { C 2013. The A } \\
\text { Licensee: AOS } \\
\text { OpenJournals. } \\
\text { is licensed unc } \\
\text { Creative Comn } \\
\text { Attribution Lic }\end{array}$ & $\begin{array}{l}\text { IS } \\
\text { This work } \\
\text { ler the } \\
\text { nons } \\
\text { ense. }\end{array}$ \\
\hline Read online: & \\
\hline 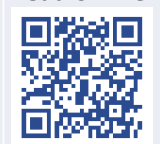 & $\begin{array}{l}\text { Scan this QR } \\
\text { code with your } \\
\text { smart phone or } \\
\text { mobile device } \\
\text { to read online. }\end{array}$ \\
\hline
\end{tabular}

This article deals with the approach to exegesis of biblical narrative, especially in Exodus, in finding its theological significance for contemporary and relevant biblical interpretation. It shows that the historical-critical method is unable to span the divide between the original context and our contemporary context, and to provide the present relevance of Scripture. After arguing for the validity of a set canonical text, this article shows that biblical narrative in general, and the Exodus narratives in particular, are best explored theologically by means of a canonical approach. It shows that the theological significance translates more easily into life-application. It demonstrates how the Exodus narratives are employed canonically for its theological significance throughout the Bible. It concludes that the Church needs teachers who recognise their responsibility to accurately interpret their whole Scriptures, the Bible, with the necessary historical, linguistic (rhetorical) and theological considerations, and that this is best done in a canonical context - whether we use a synchronic or a diachronic approach.

\section{Introduction}

There are broadly three ways in which the Bible is viewed. Firstly, there are those who view the Bible as they would any other literary work. It must be judged according to the same criteria whereby other literary works are judged. The Bible is not considered to be unique in any way. They do not recognise revelation and its validity as an epistemological principle in the Bible. Hasel (1978:27) concludes that the priority of reason over Scriptural revelation is realised at the expense of the authority of the Bible. Revelation raises the question of authority and, in turn, authority raises the question of canon, or vice versa (Clements 1978:19). For them, the theological concern does not dominate. The fact is that only the theological relevance is translatable to our context.

Secondly, there are those who venerate one part of the Bible above another. They see the Old Testament as either more or less authoritative than the New Testament. In most cases, the Old Testament is declared irrelevant. McKenzie (1974:319), for instance, follows A. von Harnack and R. Bultmann in his affirmation that the Old Testament is not a Christian book. Bultmann (1964:14) overtly states that the history of Israel is not the history of revelation, and thus it is nothing more than a presupposition of the New Testament. Marcion and others went wrong by trying to excise the Old Testament from our canon of Scripture. With the veneration of some parts of the Scriptures, we often encounter the idea of a canon within a canon, which is a human-determined canon.

Finally, there are those who accept the Bible as the Word of God. They see it as revelation, but as revelation in history, and therefore on a different plane than all other writings. The canon is seen as the exclusive and full scope of authoritative Scriptures. They understand that, apart from its own additional revelation, the New Testament is largely fulfilment and application of the Old Testament. There is therefore continuity between the two testaments, and the one cannot fully make sense without the other. This continuity is found on the plane of theology. So, that which was able to connect the history of the Old Testament with the history of the New Testament was theology. This very continuity actually forms the basis of continuous relevance, even for our contemporary context.

Our aim is to show that biblical narrative in general and the Exodus narratives in particular, are best explored theologically by means of a canonical approach. The canonical reading of the Bible allows both history and theology to work in tandem for the benefit of the community of faith. The historical aspects, though necessary to be explored, are not best explored by the historical-critical method as it is known. We propose that the scope of historical investigation be one that does not seek to decide on the extent of the canon of Scripture, but one that objectively works with the canon of the faith community. We show that the canon uses the Exodus-motif throughout, so that we in fact have an example of a canonical reading of the Exodus narratives applied theologically. 


\section{There is a place for the historical (-critical) method}

We recognise the need for uncovering the historical information, and agree with Le Roux (2007a:5) that more and more scholars experience an elusion of the true meaning and a feeling of disillusionment with the method that excludes historical information. The Scripture is revelation where the words and works of God are recorded. Scripture is, however, also a historical document reflecting the stories of Israel and the Church. The revelatory and historical aspects of Scripture require both a theological method and a historical method of investigation. Fact and faith are not mutually exclusive terms, and any investigation into Scripture must treat both as necessary. Any extreme to one side or the other will prove both impotent and dangerous. I.J. du Plessis (1975) demonstrates this point eloquently:

The first extreme wants to discard critical investigation but runs the danger of ending up in superstition. This proposition also inclines towards a fundamentalistic approach to Scripture which in turn leads to a docetic view of Scripture and Revelation. And this would undermine the absolute claim of the Christian faith rather than support it. The second extreme where faith is rejected in understanding reality is also unacceptable because the question arises whether that which is understood is still reality and truth. There is a growing consensus today that reality and truth is more than that which can be proved reasonably and empirically. (p. 6)

Whilst Du Plessis' stance is clear, it seems to refer more to a historical than to a critical method that must go with the theological method. Meier (1977:50), after exposing the historical-critical method as fruitless over its 200-year reign, admits that a historical method must be employed in biblical exegesis, but not a critical method. He later defines that the historical method to be employed is a historical-Biblical method. The objections Meier raises against the historicalcritical method is that, contrary to its agenda, it is impossible to discover a canon in the canon, and the Bible does not permit itself to be separated into a divine Scripture and a human Scripture. He (ibid:16-25) states that revelation is more than subject matter; in it the conclusion is established prior to the interpretation; that method displays deficient practicability in the church; and critique is not the appropriate answer to revelation.

Linnemann (1990:85-88) concurs with Meier in her critique of historical-critical theology: that the Bible is no longer esteemed as God's Word, and that it is taken for granted that the words of the Bible and God's words are not identical. Since the inspiration of Scripture is not accepted, it cannot be assumed that the individual books of Scripture complement each other. For historical-critical theology, critical reason decides what is reality in the Bible and what cannot be reality, and this decision is made on the basis of the everyday experience accessible to every person - that which is generally held to be possible. Du Plessis (1975:13) sums up that the limitations of historical-criticism lie mainly in the fact that it depends on the autonomous human reason as criterion. This is also the reason for the shortcomings of Troeltsch's three principles viz. that they are Cartesian in origin and work solely on rational principles. It is unable to do justice to the biblical text without the principle of perception, as no human science can penetrate God's actions in history. There is therefore no place for miracles.

Unfortunately, through the influence of Semler (1725-1791), Lessing (1729-1781) and Herder (1744-1803) there has been a decline in the notion of canon. It propagated that all Scripture is not all God's Word. They propagated that Scripture must be understood in the same way as it is understood when it originated. In itself this is not wrong, but it severed itself from the attempt to produce a synthesis between the historical and the theological understanding of Scripture. Historicalcriticism can indicate the form in which the kerygma comes to us and analyse it, but it cannot do justice to the purpose and theological meaning of a given text.

Many believe that the exegetical task must chiefly be a 'scientific' task. The terms upon which theology is to take the historical (-critical) method seriously, is when that method realises that the principles of research are freed from an ideological anthropocentrism that denies absolutely the dimension of transcendence in reality (Braaten 1966:44). The approach that defends a purely rationalistic method will end up in a cul-de-sac, because the Bible is not a merely secular document. The historical method can help the exegete to be as objective as possible. We agree with Du Plessis (1975:14) when he cites E. Jüngel: 'Theology need not be unscientific while it thinks theologically'. Theology as a science cannot work only empirically. Serious exegesis of biblical texts can therefore take place in a suitable historical way only when the different methods are applied so that they can control and correct one another. We must therefore accept, with Gorman (2009:12), that exegesis is both a science and an art, whilst not forgetting its supernatural character.

The higher historical-critical method has as its basic presupposition the view that history is a closed continuum, an unbroken series of causes and effects in which there is no room for transcendence (Ebeling 1963:79-97). In this instance, we value Hasel's (1991:198) observation. He believes that the method that prides itself on its scientific nature and objectivity turns out to be in the grip of its own dogmatic presuppositions and philosophical premises about the nature of history. Another dissenting voice, is Miscall's (1992) when he says the following about historical criticism:

[T] he atomistic strategies that divided and sub-divided the biblical texts into sources and their diverse parts, and the assumption that meaning lies in reference to an extra-textual historical reality must be avoided. (p. 39)

Professor Adam (1996:397-410) concludes that historical criticism cannot justify claims that it is the only sound theological approach to biblical interpretation. Historical criticism cannot be the guardian of contemporary orthodoxy. 


\section{History and the Canonical approach}

Klingbeil (2003:403) correctly observes that, if the biblical text is only a collection of diverse ancient texts as historical criticism posits, then it cannot claim an authority in terms of its content. It follows that the usual text-critical method, which results in each successive generation of critics offering fresh suggestions regarding the form of the original text, is highly individualistic and it seems to be unaware of the enduring role of the canonical text and its authoritative function for ongoing faith communities. However, if the biblical text began with revelation from a being outside our own system, then the issue of authority needs to be addressed from a different angle. We say that that angle is from a canonical context. The Scriptures of the Church function as the vehicle for God's special communicating of himself with his people and the world, and is therefore authoritative. If the decision on canon was only historically conditioned, why should we be limited to them in our contemporary theological work? Theology must have an authoritative base, which it finds in the Canon.

Canonisation was chiefly an expression of faith in its whole process (Childs 1970:104). The canon exists in its final state as our Scriptures by the providence of God. Henry (1999) agrees that it came about by faith and providence. He continues to say:

Historical observation can neither demonstratively prove nor disprove the operative providence of God in history. Nor can it demonstratively certify that Jesus did or did not rise from the dead. Nor, for that matter, can the historical method indubitably establish that Jesus was crucified by Roman soldiers, or even that Caesar crossed the Rubicon on some past momentous day, however 'probable' it may be that he crossed the Rubicon routinely, if indeed he crossed it at all. Historical research is therefore equally limited in investigating both biblical and secular claims about the past. Whether conducted by Cornelius Van Til or by Arnold Toynbee, historical investigation provides only provisional and not certain knowledge of the past. (p. 316)

Childs (1970:141) argues further that the historical-critical method is an inadequate method for studying the Bible as the Scriptures of the Church, because it does not work from the needed context. He goes on to say that the historicalcritical method is seen to be inadequate for the theological task of exegesis from the evidence in the modern concept of biblical commentary. Exegesis as a theological discipline has been lost (Childs ibid:142). It is not to say for a moment that the critical method is incompatible with Christian faith, but when operating from its own chosen context, it is incapable of either raising or answering the full range of questions that the Church is constrained to direct to its Scriptures. The critical method proves to be inadequate because it sets up an iron curtain between the past and the present. Klingbeil (2003:403) concurs with the conclusion that historical criticism tends to imprison the biblical text in the past without providing 'objective' tools to uncover that past.

The text must primarily be seen as a theological text, being aware of the challenges of applying the appropriate theological task of biblical interpretation (Gorman 2009:117). Henry (1999) demonstrates the point:

The impossibility of establishing theological doctrines by historical method is not here disputed. No amount of historical inquiry can prove that Jesus is the Christ, or that the Hebrews rightly believed that Yahweh rescued them from Egypt. (p. 315)

'It is hard to overemphasize the impossibility of obtaining historical evidence for the view that certain events are "the mighty acts of God"', writes John Marsh (1952:7).

It must be emphatically stressed that there is a divine dimension in biblical history that the historical-critical method is unable to deal with. For this reason, Old Testament scholarship is changing from a purely historical-critical methodology to one that focuses on bigger text-portions. Le Roux (2005) advises:

Een so 'n moontlikheid (vir die studie van die Pentateug) is om voorlopig literêr-kritiese analise te vermy en eerder op die groot vorm (Enneateug) en teksblokke (soos die aartsvaders en die uittog) te fokus. In die proses kan die pastorale waarde van die Pentateugkritiek ook beklemtoon word. [One such possibility (for Pentateuchal studies) is to avoid literary-critical analysis in the meantime in order to focus on the larger form (Enneateuch) and pericopes (like the Patriarchs and the exodus). In this process, the pastoral value of Pentateuch-criticism may be emphasised.] (p. 27, [author's own translation])

This statement betrays some openness to a canonical view.

The canonical context allows, in the different layers, the interaction that provides a holistic theological interpretation. The environment of this interpretation is the Protestant tradition (Jolley 1987:2). Childs (1985:13) illustrates that, though historically the Old Testament law was often of a different age and was transmitted from much of the narrative tradition, the canonical approach is able to exploit it in theological interaction. The canonical shape of a given text has a theological purpose and a theological effect (Jolley ibid:36). Elsewhere, Childs (1964) objects to a purely historical and descriptive approach on account of its limiting nature.

What should historical investigation entail? The following points are helpful aspects of history to follow in our investigation. This kind of investigation does not make any judgments on the canonicity of the text:

- The historical background. The history of the Ancient Near East, contemporaneous to the biblical narrative, enhances our understanding of those times. Here we include things like conventions, geography, population, et cetera.

- Archaeological history of biblical purport.

- Manners and customs of Bible times.

- Historico-religious comparisons.

- Inner biblical literary sources and forms (hymns, prayers, creeds, etc.) of the earliest congregations.

- Biblical epochs - the programmatic outlook (e.g. heilsgeschichte) where temporal (past, present, future, eschatological) dimensions and divine economy (Law and Grace, shadow and reality, etc.) are considered. 
- The history of interpretation as additional help to analyse theological conclusions.

Le Roux (1994:201) veers in this direction when he admits that, more important than the historical-critical method, which is waning, is a historical understanding of the reality of the text. He later advises, with respect to Renan, that we must try to weave into the history of the Israelite story the considerations of 'the climate, the geography, the vegetation' et cetera. (Le Roux 2007b:992). We agree that this kind of historical information endows the story with life and energy. This history, however, is not necessarily the history of the time of narration (Groenewald 2007:120-121). From a canonical perspective, we are to be concerned with the history in the narrative.

From a canonical context, the question of Geschichte [events are embedded in the ongoing march of time and receive different interpretations over the years] or Historie [the bare facts of events that took place and that can be checked] is settled, because the canonical approach views history from the perspective of Israel's faith-construal, so siding with Geschichte. Kerygmatic and salvation (heils-) history also place themselves in the Geschichte camp, but are often accused of having a too narrow view of history. Although different dimensions of history are freely recognised, by focusing on Israel's historical role as the bearer of the traditions of faith, these two aspects of history (Geschichte and Historie) are held together in a subtle balance within the shape of the canon, and should not be threatened by some overarching theory of history (Childs 1985:16).

Lawrie (2009:4) comments that we can now make some fairly confident statements about the material culture, economic life and social structures of Israelite villages and cities. In practically every area, comparative studies, drawing on increased knowledge of the Ancient Near Eastern world, has enriched or modified our previous insight. He continues by saying that it must be recognised that literary history alone cannot answer the problems presented by the text (Lawrie ibid:6). To this last statement, Claassens (2009:17) responds: '... in interpreting the text ... use numerous tools including historical and literary tools, ideological criticism etc. to foster good exegetical practices.'

\section{The canonical text}

We need to ask: what is the canonical text? By canonical text we mean the text that, after some process, came to be accepted by the faith-community as their authoritative Scriptures. There first came a time of stabilisation as part of the acceptance of the text. Formal acceptance may have come long afterwards. Childs' (1979:98-101) comments, that when we speak about the stabilisation of the Hebrew text, it must be understood that the stabilised Hebrew text of the Jewish community was only a consonantal text. When the Hebrew text of the Jewish community reached the point of stabilisation in the first century AD, the term 'canonical text' could be applied to it. That became the normative and authoritative form of Israel's sacred scripture. Childs (ibid:106) reminds us that the effect of taking the canon seriously is to establish the level of the biblical literature in accordance with its historical stabilisation by the Jewish community, and to seek to understand this received text in the light of its historical development. Historian Kevin Roy admits that whether or not Jamnia was that point does not really matter, because Judaism had already formulated a consensus canon, which Jamnia would only have 'rubberstamped' (Roy 2010).

In this regard, we have to admit that the Masoretic text (MT), though not identical to the canonical text, was indeed the vehicle for its recovery. The Qumran manuscripts support the actual task of recovering a text close to the first century proto-MT type. The present MT was developed from an earlier proto-MT that extended back into the pre-stabilisation period (Childs 1979:100-103). The selection of the protoMT as the dominant tradition by rabbinic Judaism in the first century AD, did not arise from an arbitrary, academic decision as once postulated, but was rather the culmination of a long, recessional history. Its choice as the canonical text was determined by sociological factors and internal religious conflicts, and not by scholarly textual judgments.

\section{The pervasiveness of Exodus and its themes}

If, for example as Motyer (2005:20) echoes Eichrodt (1969: 36-39, 70-74) and Mendenhall (1962:714-723), it is true that Exodus is a covenant narrative and that the covenant is the mainspring of the book, then immediately we find a theological theme of importance. Thereby, or with correlating concepts like Kaiser's (1978) blessing-promise, Exodus is connected to Genesis by the patriarchal promise and to Leviticus, Numbers and Deuteronomy by the movement towards the Promised Land. This very theme binds Exodus to the whole Bible by two great moments as the expression of the covenant and creed namely, the name of the Lord ('I am Yahweh your God ...') and, in Exodus 20:1-2, his redemptive work ('... who brought you out of the land of Egypt'). His personal name specifically portrayed God as present with and for his people. The Passover sacrifice has been ordained by Yahweh as a perpetual reminder to the people of his redemptive activity. This is the point at which Exodus gives a 'new beginning' and a paradigm of future redemptions. The ultimate redemption is found in Jesus Christ, the Son of God and the Lamb of God who takes away the sins of the world (Jn 1:29-36).

Motyer (2005:23) comments that, whilst some of these great biblical truths are foreshadowed in Genesis, Exodus pulls them all together, giving them a shape and definition that the rest of the Bible will not alter. Under the simplest of forms, and by many a fascinating story, Exodus reveals fundamental truth and is in fact one of the Bible's great building blocks. We can give many examples of the Exodus-remembrances in the Old Testament. There are occurrences in almost all of the historical books (e.g. Jos 2:10; Jdg 11:15-22; 1 Sm 10:17-19; 
2 Sm 7:23f.; 1 Ki 8:15f.; 2 Ki 17:36; Neh 9:9-23). Though absent from the other Wisdom writings, there are many instances in the Psalms (e.g. Ps 78:12-54). The prophets also have many allusions to the exodus-events (e.g. Is 51:10; Jr 2:6f.; Dn 9:15f.; Hs 13:4-6; Am 2:10; Mi 6:4; Hab 3:8-10; Hg 2:4-7). In the New Testament, the very work of salvation brought about by Jesus Christ is often expressed in terms of the Exodusredemption imagery. An example of connection to the New Testament can be demonstrated with the Gospel according to Matthew. Israel, God's 'firstborn son' (Ex 4:22), was to dedicate its firstborn sons to God. The firstborn Son of God, Jesus' life, like the existence of Israel, was threatened by the contemporary political authorities (Mt 2:13ff.), and he came through the waters (Mt 3:1) into the wilderness ( $\mathrm{Mt} \mathrm{4:1)}$ to be tested. Israel, the son, needed salvation and Jesus, the Son, brought salvation.

The pervasive nature of the Exodus story and the perpetual remembrance of the Passover force upon us a more unified and developing redemptive theology. The Old Testament interpretation of the Exodus-motif is reflected as a history of tradition, which may be discovered from a diachronic reading. Von Rad (1965) in his two-volume Old Testament Theology sought to unfold Israel's theological activity by means of the diachronic tradition-historical method using the canonical (fixed) text of the Old Testament. He shuns the historical-critical method because its 'investigation searches for a critically assured minimum - but the kerygmatic picture tends towards a theological maximum' (1965:108). For him, the phenomenon of Israel's faith itself, which speaks now of salvation, now of judgment, is beyond historical criticism's power to explain. Hasel (1991:72) comments that Israel with her testimonies speaks from such a deep level of historical experience that historical-critical research is unable to reach. The testimony that Israel herself gives concerning Yahweh, namely, the word and deed of Yahweh in history, presents neither pure revelation from above, nor pure perception and presentation from below. Pereira (2010:50) comments that by celebrating the Passover, the Israelites had become perpetual witnesses of the redemption of Yahweh. Theologically, this event carries so that we too may become witnesses of Jesus Christ, our Passover (1 Cor 5:7).

\section{The significance of the canonical approach and theology}

According to Childs (1985:23ff.), canonisation changed profane literature into sacred by rendering it qualitatively different from its origins because it was also to address future generations with the reality of God. Childs (1979:52) sees the first step in the process as Josiah's reform of $621 \mathrm{BC}$, reported in 2 Kings 22, and the final stage of the Old Testament was assigned to the decisions at the Council ${ }^{1}$ of Jamnia (c. AD 90).

1.There is debate whether Jamnia actually was a council or just a school. Either way it did happen and there is evidence that a discussion was held at Jamnia on the canonical status of Ecclesiastes and the Song of Songs, but this is not enough to suggest that any binding or official decisions were made. A 'general consensus already existed regarding the extent of the category called Scripture, so that even the author of 4 Ezra, though desiring to add one of his own, was obliged to recognize this consensus in his distinction between public and hidden Scripture (Newman 1983:348-349).
Canonisation is a human-divine process - God's people together with God's providence brought about the finalised canon of Scripture. Even though we believe that it was sacred from its origins, the point is taken that the canon cannot be divorced from the idea of revelation and providence, and that the term 'revelation' reflects the concern to be open to the theological dimensions of the biblical canon. Revelation, through creation, wisdom, history and verbal means, is seen as the communication of a self-disclosing God. God is not limited to any means of revelation, and the purpose of his revelation is to make himself known and to provide salvation or redemption for his creation. The reality of the Kingdom of God is realised amongst people through the provision of salvation. God revealed himself in the real events of human life; therefore revelation and history go together (Childs 1970:42). Faith is the means of apprehending revelation. Canonisation was chiefly an expression of faith in the whole process. Therefore, the role of theological reflection is to derive a contemporary relevance.

It is the Old Testament's faith in God that also opens the possibility of Christian interpretation, and thus relevance to ensuing ages in Christianity who accepts the canon as their own Scriptures. The theological process is the only means by which the will of God may be known; it cannot come through historical or literary solutions (Childs 1985:58f.). From a canonical perspective, what the text meant and what it means are inseparably linked and both belong to the task of the interpretation of the Bible as Scripture. The canonical approach takes the unity of the Bible, and the relationship between the Old Testament and the New as more than just a theoretical concern. The New Testament itself shows an unbroken sense of continuity between the God of Israel and the God worshipped by Christians. The Old Testament is used by the apostles with no tension to develop their Christology.

Whether we view our texts synchronically or diachronically, by using its canonical underpinnings, we are best able to derive its theological significance. Noth (1959:18) agrees with the thinking that theology is best explicated from the 'final form'. Only the canonical form of the biblical text is normative for any Biblical theology. Synchronic biblical analysis, according to Vervenne (1994), is not very common amongst German biblical scholars. Their diachronic methodology, with a purely historical referential, has at times lost the given text of Scripture in its analysis (cf. Otto in Le Roux 2007a:24). The purely historical referential reading is theologically inadequate as it reorders the text diachronically and in so doing misses the Old Testament's unique message (Childs 1985:153). Canonical study concerns itself with doing justice to the integrity of the text itself apart from diachronistic reconstruction (Childs 1970:74). Scripture must therefore be seen as a unity, which extends to the unity of Old and New Testament, but the Old Testament comes first.

We agree with Van Zyl et al. (1979:72) that Exodus, as with the rest of the Old Testament, is kerygmatic history, in other words history with a message, and is therefore also theological 
in nature. The ancient authors sought to influence rather than purely describe life of their time (Hopkins 1994:214). Even though it is kerygmatic or preaching history, it nevertheless remains history of events that actually took place. The harmony amongst the Pentateuchal writings will reflect the general sequence of events as they happened in Israel's early history. The events are not imposed in order to merely serve as encouragements for later situations regarding Israel. They were, for the most, real events that happened.

Though we are influenced constantly by our Christian mindset, we must attempt to draw and present our themes, motifs and concepts from the Old Testament itself without imposing the New Testament. Old Testament theology must not be Christianised (Childs 1985:9). The Old Testament is a literary work in its own right and should be interpreted as such (Vervenne 1994:92). As Christians we will, however, in our study of the Old Testament always move from the Old Testament text to our Christian beliefs. Old Testament theology is more than the theology of the Hebrew Bible. The theology of the Old Testament implies the larger context of the Bible of which the New Testament is the other part. For the Christian there is, and always must be, a relationship between the two testaments.

With reference to Exodus and its impact on the rest of the Bible, a biblical theology that tends to use a thematic approach is almost unavoidably diachronic as it considers development of the theology in the Bible. Ethical interests can be derived from biblical theology. Our ethical interest must finally be applied to society, and we believe that there is and must be a mutual 'flow' between religion and society. God's people are his agents in this process. We agree with Le Roux (1998:304) when he says:

Godsdiens vorm 'n integrale deel van die samelewing. Van die antieke gemeenskap was dit besonder waar. Godsdiens was alles-bepalend...Godsdiens kan nie los van gemeenskapkragte ... gesien word nie. [Religion is an integral part of society. This is particularly true about ancient community. Religion was allencompassing... it cannot be understood as separate from social forces.] (p. 304, [author's own translation])

\section{Conclusion}

In addition to Le Roux's normal process of historical development and possibility, we accept also that divine intervention, through spiritual revival, can make speedy societal change possible. God often uses the believing community to this end. We must forever hold on to the faith that the present God can use what he has given us to affect our current society. Also, we would do well to heed O'Kennedy's (2009:24) advice that if Old Testament scholars are unwilling to walk the second mile with the church, the message of the Old Testament may become gaunt. Those who only focus on the New Testament or on certain passages of the Old Testament will have an inadequate understanding about God and his relation to humanity. We cannot afford that pastors are no longer specialists in the interpretation of God's Word. We in South Africa are in desperate need for people to live the biblical values of humanity and social justice (O'Kennedy ibid:18). The book of Exodus is vital in our biblical understanding of God, soteriology and society. On this issue, Wright (2009) aptly comments that:

... the Bible as a whole conveys the whole good news ... is the complex phenomenon we call the canon of Scripture... [which] in all its canonical parts, contributes to the good news ... and must function to control the criteria by which we are able to discern what makes the good news truly good, and what is actually bad news disguised as good ... but false alternatives. (p. 4)

\section{Acknowledgements Competing interests}

The author declares that he has no financial or personal relationship(s) that may have inappropriately influenced him in writing this article.

\section{References}

Adam, A.K.M., 1996, 'Docetism, Kasemann, and Christology', Scottish Journal of Theology 49(4), 391-410. http://dx.doi.org/10.1017/S003693060004847X

Braaten, C.F., 1966, History and Hermeneutics, Westminster Press, Philadelphia. PMid:5947654

Bultmann, R., 1964, 'The significance of the Old Testament for the Christian Faith', in B.W. Anderson (ed.), OTCF: A theological discussion, pp. 8-35, Harper \& Row, New York.

Childs, B., 1964, 'Interpretation in faith', Interpretation 18, 432-449.

Childs, B., 1970, Biblical theology in crisis, Westminster Press, Philadelphia.

Childs, B., 1979, Introduction to the Old Testament as Scripture, Fortress Press, Philadelphia.

Childs, B., 1985, Old Testament theology in a canonical context, SCM Press, London.

Claassens, L.J.M., 2009, “'Quo Vadis” Old Testament studies? - A response', Scriptura 1(100), 15-17.

Clements, R.E., 1978, Old Testament Theology, Marshall, Morgan \& Scott, London.

Du Plessis, I.J., 1975, The historical-critical method - Its necessity and limitations, University of Zululand, Kwa-Dlangezwa.

Ebeling, G., 1963, Word and faith, SCM Press, London.

Eichrodt, W., 1969, Theology of the Old Testament, vol. 1, SCM Press, London.

Gorman, M.J., 2009, Elements of Biblical Exegesis, Hendrickson, Peabody.

Groenewald, A., 2007, 'Changing paradigms: Old Testament scholarship between synchrony and diachrony', in J.H. le Roux \& E. Otto (eds.), South african perspectives on the Pentateuch between synchrony and diachrony, pp. 108-123, T\&T Clark, London.

Hasel, G., 1978, New Testament theology: Basic issues in the current debate, Eerdmans, Grand Rapids.

Hasel, G., 1991, Old Testament theology: Basic issues in the current debate, Eerdmans, Grand Rapids.

Henry, C.F.H., 1999, God, revelation, and authority, Crossway Books, Wheaton (Original work published c1976-c1983).

Hopkins, D.C., 1994, 'Life in Ancient Palestine', in L.E. Keck (gen. ed.), The New Interpreter's Bible Commentary, pp. 213-227, vol. 1, Abingdon Press, Nashville.

Jolley, M.A., 1987, The canonical approach of Brevard Childs, Southern Baptist Theological Seminary, Michigan.

Kaiser, W. Jnr., 1978, Toward an Old Testament theology, Zondervan, Grand Rapids.

Klingbeil, G.A., 2003, 'Historical Criticism', in T.D. Alexander \& D.W. Baker (eds.) Dictionary of the Old Testament - Pentateuch, pp. 401-420, InterVarsity Press, Dictionary
Leicester.

Lawrie, D., 2009, 'Old Testament studies: “Quo Vadis”?', Scriptura 1(100), 1-14.

Le Roux, J.H., 1994, 'Historical criticism - The end of the road?', Old Testament Essays $7(4), 198-202$

Le Roux, J.H., 1998, 'Godsdiens het die politiek nodig en die politiek is weerloos daarsonder', Skrif en Kerk 19(2), 301-313.

Le Roux, J.H., 2005, 'Die Pentateuch tussen deel en geheel', Old Testament Essays $18(2), 265-280$.

Le Roux, J.H., 2007a, 'Setting the scene: The battle of the signs', in J.H. le Roux \& E. Otto (eds.), South African perspectives on the pentateuch between synchrony and diachrony, pp. 1-18, T\&T Clark, London.

Le Roux, J.H., 2007b, 'Historical understanding and rethinking the foundations', Hervormde Theological Studies 63(3), 983-998. 
Linnemann, E., 1990, Historical criticism of the Bible: Methodology or ideology?, Baker Books, Grand Rapids.

Marsh, J., 1952, The fullness of time, Harper \& Brothers, England.

McKenzie, J.L., 1974, A theology of the Old Testament, Macmillan Press, Garden City.

Meier, G., 1977, The end of the historical-critical method, Concordia Publishing House, USA.

Mendenhall, G., 1962, 'Covenant', in G.A. Buttrick (ed.), Interpreter's Dictionary of the Bible, pp. 714-723, vol. 1, Abingdon Press, Nashville.

Miscall, P.D., 1992, 'An experimental journal for Biblical criticism', Semeia 60, 39

Motyer, A., 2005, The message of Exodus, InterVarsity Press, Leicester.

Noth, M., 1959, Exodus, SCM Press, London.
Newman, R.C., 1983, 'The council of Jamnia and the Old Testament canon', Westminster Theological Journal 38(4), 319-349.

O'Kennedy, D., 2009, '"Quo Vadis" Old Testament studies? - A response', Scriptura $1(100), 18-29$

Pereira, G.C., 2010, 'The Exodus Redemption as Paradigm for Christian Evangelism', in G. Harold (ed.), The South African Baptist Journal of Theology, pp. 45-55, Baptist Union of Southern Africa, Cape Town.

Roy, K., 2010, 'Interview - Church history and canonization', BTC, Randburg.

Van Zyl, A.H., Eybers, I.H., Le Roux, J.H., Prinsloo, W.S., Swanepoel, F.A. \& Vosloo, W., 1979, Israel and her neighbours, Butterworths, Durban.

Vervenne, M., 1994, 'The sea narrative revisited', Biblica 75(1), 80-98.

Von Rad, G., 1965, Old Testament theology, vol. 1, Oliver \& Boyd, Edinburgh.

Wright, C., 2009, "According to the Scriptures" The whole Gospel in Biblical revelation', Evangelical Review of Theology 33(1), 4-18. 